\title{
BUCHAREST PUBLIC TRANSPORT: CHALLENGES DURING THE COVID-19 PANDEMIC
}

\author{
Andreea Daniela TUDOR \\ Bucharest University of Economic Studies, Bucharest, Romania \\ tudorandreead@yahoo.com
}

\begin{abstract}
The COVID-19 pandemic had and it's still having a big impact on mobility since the end of 2018, when it started. Public transportation was already facing issues in all the big metropolitan cities where many people are in the same space at the same time. If we add the COVID-19 consequences and rules, public transit is the main barrier for community members to go back to their daily routines being safe and comfortable. This paper presents the changes in the public transport sector since COVID-19 started and aims to explore the consequences and possible alternatives to mitigate the impact of the pandemic crisis. As research method I decided to analyze and summarize numerous primary sources along with the public transport operators' official websites. Both quantitative and qualitative data were used by doing a comprehensive research in ProQuest Central, Coronavirus Research Database, Elsevier ScienceDirect and Web of Science. The results suggest that reduction of mobility has been the first measure to slow the growth of the worldwide COVID-19 cases. However, the transport limitations don't have the same impact for all modes of transport, public transport having one of the most considerable decline so far. In Bucharest, the public transport operators have imposed safety measures such as mask wearing, periodic cleaning, transparency and access to the information. Those aspects are important, but sometimes not sufficient to fight against the pandemic. What this research does is to come and complete the set of safety measures focusing on mitigating the spread of the SARS-CoV-2 virus and increase the safety of the people while using public transport vehicles.
\end{abstract}

Keywords: COVID-19, Pandemic, Public Transport, Passenger, Epidemic

DOI: https://doi.org/10.24818/beman/2021.S.I.2-08

\section{INTRODUCTION}

The COVID-19 outbreak started in the last month of 2019 in Wuhan, China. This dangerous virus was rapidly spreading in countries all over the world. World Health Organization described the situation and titled it as "pandemic crisis" in March 2020 (World Health Organization, 2020). The COVID-19 disease is caused by SARS-CoV-2 virus which can give severe respiratory illness and even death.

Many countries have taken measures to prevent the social contact and slow down the spread of the virus. Some of the measures were to close shops, schools, restaurants, bars, ban public events or introduce remote work (work from home). If we look at those measures, we can see that the goal was to 
accomplish the social distancing phenomenon, which can be efficient if we think that COVID-19 is transmitted by small airborne particles and droplets (Wilder-Smith \& Freedman, 2020). Coronavirus pandemic will be remembered as a historic event that impacted the human condition all over the globe. The consequences are likely to be seen over many years impacting human behavior, economy or by adding additional government debt (Polzin, 2021).

Transportation plays a very important role in both social and economic development of a country because it facilitates the movement of people and goods. Therefore, a good infrastructure is a precondition of a good public transportation.

Public transportation management is a very difficult task but the absence of it is even worse, meaning that can have a huge impact on education, health, life in society, economic opportunities, mainly among the poorest (Willoughby, 2002).

One of the main challenges is to ensure a safe and modern public transportation, well-planned, wellorganized, well-integrated and functional. A high quality of public transport is inseparable from its competitiveness compared to individual transport. In other words, the goal is to balance the costs borne by users and local administrations, including the accessibility of alternative means of transport (walking, cycling, etc.) (Struzik, 2020).

On the other hand, this paper also shows helpful for public transport operators who aim to improve decision making by comparing the performance of other companies with their own performance in terms of quality.

This research is starting with a comprehensive literature review which has two parts. Firstly, focusing on the impact of the COVID-19 pandemic crisis on the public transportation sector and secondly having as center of attention the impact of the pandemic on the public transportation system in Bucharest. Once the main aspects are discussed the research continues with the research methodology. Finally, this paper addresses future opportunities of research and provides recommendations for making public transport more practical and efficient while focusing on passenger comfort and safety.

\section{LITERATURE REVIEW}

\subsection{COVID-19 pandemic and public transportation}

Many countries such as Canada, Australia, United States of America, Italy, Spain and Norway comply with mobility bans. This has severely affected the transportation system around the world. Also, in Budapest, the most significant reduction in the number of trips was observed in public transport, while cycling was facing the slightest decline (Bucsky, 2020). The use of public transport by citizens has seen the largest decline in the Netherlands, where the number of journeys has been reduced by more than $90 \%$. In this country, $88 \%$ of people prefer to use other means of transport than to use public modes of 
transport (de Haas, Faber, \& Hamersma, 2020). (Aloi, et al., 2020) reported that the mobility of citizens in Spain was reduced by $76 \%$, and public transport saw a $93 \%$ reduction in the number of passengers. In the UK, travel restrictions have led to a 95\% decrease in underground travel. At the end of June 2020, Brussels, Singapore, Stockholm, Lyon, Paris and Moscow had a mobility index of more than $50 \%$. Hong Kong had the highest mobility rate of $76 \%$, while cities from the United States of America were found to have a mobility rate of less than 20\% (Abu-Rayash \& Dincer, 2020).

In Australia, the COVID-19 disease was confirmed in early 2020, in January. Similar methods have been taken to limit the spread of the virus: remote work, online learning and limited mobility possibilities (Munawar, Khan, Qadir, Kouzani, \& Mahmud, 2021). Sydney, the second largest city in Australia was facing a drastically cut of the train and bus services under the COVID-19 restrictions (ABC Premium News, 2021a). In December 2020 the capacity was lifted to $25 \%$ on light rail, $45 \%$ on buses and $55 \%$ on trains (ABC Premium News, 2021b).

(Agrawal, Tripathi, \& Agrawal, 2015) conducted a study having as main goal to measure the service quality of the public transport in Delhi, India. The research was made by using multiple decision-making methodologies to choose the best criteria. The study showed that problems related to traffic congestion or pollution can be significantly reduced by increasing the public transport quality.

In another research on public transport operations optimization, (Ceylan \& Ozcan, 2018) presented a model with two levels capable to do simulations and find benefits for both bus operators and passengers. The most important elements in public transportation are the time savings promoted by time management and investments in infrastructure. Therefore, passengers want reliable transport, arrival time being very important and affecting the choice of the users (Tirachini, Hensher, \& Bliemer, 2014). A research conducted by (Flyvbjerg, Holm, \& Buhl, 2007) shows that approximately half of the transportation projects are not reliable, mishandling traffic forecasts in around $20 \%$ of the cases.

In Tampere, one of the largest cities from Finland that has around 238.000 inhabitants the number of public transport passengers decreased with $70 \%$ in spring 2020 due to the pandemic and the consequences that came with it, namely schools being closed and remote work (Tamminen, 2020). Finland is not the only country that had a decrease, public transport being affected in many countries during the COVID-19 pandemic (Beck \& Hensher, 2020), (Budd \& Ison, 2020), (De Vos, 2020), (Bucsky, 2020). Therefore, it's very difficult to operate public transport at a normal level with a significant decrease of the passengers.

Looking at a study that was done in $2020,68 \%$ of the Romanians over the age of 18 prefer to use their personal cars as transportation mode during the pandemic, followed by public transport $(11 \%)$ and bicycles (9\%). If we reduce the range and look at the 18-50 age group, the study revealed that personal car is the first choice when it comes to transport preference $(77 \%)$, followed by bicycles $(8 \%)$ and public 
transport $(7 \%)$. Therefore, a trend can be seen, no matter what age group we take in consideration. The first preference when it comes to transport is using their personal car and very far away, we can see as a choice, either bicycles or public transportation.

\subsection{Public transport in Bucharest during COVID-19}

The capital of Romania has one of the most complex public transport networks in Europe. Therefore, the local public transport network in the capital includes an underground transport method managed by Metrorex and three surface transport methods managed by STB - "Societatea de Transport București." Surface transportation includes a vast network of buses, trams and trolleybuses comprising 133 bus lines, 24 tram lines and 15 trolleybus lines. This system is often crowded due to heavy use. The vehicle fleet includes 1147 buses, 486 trams and 297 trolleybuses (STB, 2020).

The bus network is the most extensive and complex method of transport in Bucharest, but unfortunately it does not benefit from a distinctive traffic color that is reserved for their transport and as a result the transport speed is extremely reduced, especially during peak hours.

Bucharest tram network has a separate path from the main road aiming to avoid the entry of cars. Therefore, trams can reach higher speed during peak hours, respecting the security conditions and not endangering the safety of passengers or other traffic participants.

Trolleybuses are electric vehicles for public transport. These vehicles often look like a regular bus but are powered by one or more electric motors. The trolleybus lines make the connection between east and west.

The underground transport network managed by Metrorex is one of the most used means of public transport in Bucharest, with a network length of $77 \mathrm{~km}$ kilometers, double rail, arranged in 5 metro lines and 63 subway stations (METROREX, 2021).

(Popescu, 2020) claims that underground transportation transit has decreased between 2019 and 2020:

TABLE 2.1. THE BUSIEST BUCHAREST SUBWAY STATIONS IN THE MORNING, RUSH HOUR 8-9 am

\begin{tabular}{|c|l|l|l|}
\hline Subway Stations & $\begin{array}{c}\text { Average number of } \\
\text { passengers in } \\
\text { September 2019 }\end{array}$ & $\begin{array}{c}\text { Average number of } \\
\text { passengers in } \\
\text { September 2020 }\end{array}$ & $\begin{array}{c}\text { Increase/Decrease in } \\
\text { number of } \\
\text { passengers between } \\
\text { September 2019 and } \\
\text { September 2020 }\end{array}$ \\
\hline 1 Decembrie 1918 & 18.699 & 25.766 & +7.067 \\
\hline Piața Sudului & 83.065 & 31.109 & -51.956 \\
\hline Crângași & 77.202 & 25.859 & -51.343 \\
\hline
\end{tabular}




\begin{tabular}{|c|l|l|l|}
\hline Eroii Revoluției & 69.161 & 28.687 & -40.476 \\
\hline Dimitrie Leonida & 69.922 & 26.983 & -42.939 \\
\hline
\end{tabular}

Source: Adapted from (Popescu, 2020)

TABLE 2.2. THE BUSIEST BUCHAREST SUBWAY STATIONS IN THE EVENING, RUSH HOUR 5-6 pm

\begin{tabular}{|c|l|l|l|}
\hline Subway Stations & $\begin{array}{c}\text { Average number of } \\
\text { passengers in } \\
\text { September 2019 }\end{array}$ & $\begin{array}{c}\text { Average number of } \\
\text { passengers in } \\
\text { September 2020 }\end{array}$ & $\begin{array}{l}\text { Increase/Decrease in } \\
\text { number of } \\
\text { passengers between } \\
\text { September 2019 and } \\
\text { September 2020 }\end{array}$ \\
\hline Aurel Vlaicu & 144.305 & 37.980 & -106.325 \\
\hline Unirii 1 & 58.248 & 28.622 & -29.626 \\
\hline Aviatorilor & 64.880 & 25.355 & -39.525 \\
\hline Universitate & 55.839 & 24.981 & -30.858 \\
\hline Unirii 2 & 53.119 & 24.684 & -28.435 \\
\hline
\end{tabular}

Source: Adapted from (Popescu, 2020)

It can be seen a decrease between September 2019 and September 2020. If we look at the morning rush hours the highest decrease is 51.956 but an increase in the number of passengers that were transiting "1 Decembrie 1918" subway station. On the other hand, between the evening rush hours a decrease in the number of passengers can be seen at every subway station. The highest drop is registered at the "Aurel Vlaicu" subway station, where most corporate headquarters are located.

Lucian Bode, the Minister of Transport, stated that for Metrorex, the decrease in number of passengers with about 30-40\% generated losses of 9-10 million euros (Nedelea \& Ispas, 2020).

To increase the comfort of public transport, and to ensure a safe environment, STB promotes the following: it's important if each passenger considers the recommendations on social behavior responsible for preventing the spread of the new coronavirus. Therefore, the public transport company recommendations are to (STB, Măsuri pentru evitarea infectării cu virusul Covid-19 (coronavirus)):

- Wear the mask throughout the trip;

- Keep 1.5 meters from other passengers while using public transportation;

- Not stand in front of other passengers;

- Use alternative ways to purchase and pay for the trip: upload the nominal card online, pay via the 24Pay application, pay by SMS or pay by contactless bank card directly at the validator.

- Wait for the next means of transport if the one that just arrived it's crowded.

Similar recommendations for limiting the spread of COVID-19 infection are also imposed by (METROREX, 2020). 
Aldo we are still going through a challenging period in all industry sectors, a price increase in the STB and Metorex tickets is observed during the pandemic. A trip by bus, tram or subway is around 0.61 euros in Bucharest, from 1st of August 2021. The entire public transport system in the Bucharest - Ifov area was integrated, so there isn't a tariff difference between urban, regional and express lines and passengers are able to travel both on surface, or using the subway, with the same ticket, in a certain amount of time. So far, a STB ticket was 0.26 euros, and a subway trip, 0.50 euros. Moreover, STBMETROREX introduces a 24-hours or 72-hours subscription, a 7-days subscription, monthly subscription and even a 6-months or 12-months subscription (Ciobanu, 2021).

\section{RESEARCH METHODOLOGY}

This paper includes an analysis of the documentation that was found in various scientific articles and publications regarding the impact of the pandemic over the public transportation system. As methods, I used both quantitative and qualitative data having as main goal to explore all the consequences and possible alternatives to mitigate the impact of the pandemic crisis.

The information presented in this paper was found by doing a comprehensive research in ProQuest Central which is the largest single periodical resource and includes complete databases across all major areas of interest, Coronavirus Research Database which includes medical research databased related to the COVID-19 pandemic crisis, Elsevier ScienceDirect or Web of Science.

\section{RESEARCH RESULTS AND DISCUSSIONS}

Some of the measures that will help stop the spread of COVID-19 death and, at the same time, help public transport companies keep their doors open are to reduce non-essential routes and support essential transport during the pandemic.

Analyzing previous studies I came to the conclusion that all countries affected by this virus have imposed measures to stop the infection of the population with the virus. Imposing safety measures such as mask wearing, periodic cleaning, transparency and access to the information. Those aspects are important, but sometimes not sufficient to fight against the pandemic. Some contries agreed with this and imposed stricter protection measures.

Public transport operators also had to face another major challenge. A significant decrease in the number of passengers has been seen because most of the people who used to work in the office are now working from home. The same applies to students who have now switched to online learning.

An opportunity for this period of crisis may be the construction or modernization of infrastructure, which could continue and even increase in intensity, amid the massive reduction of traffic and by attracting additional labor, made available in other economic sectors. The development of a real sustainable 
transport system, by reducing current intermodal imbalances and stimulating the development of transport.

In Bucharest, the capital of Romania, the model explained above also applies. Mobility has been reduced due to both lockdown and remote work or online learning. Currently, the public transit it's looking a little bit better. The willingness of the population to use public transport to the detriment of the personal car has increased and is related to two factors: the feeling of comfort and the feeling of safety. To ensure the previous two factors, in Bucharest, public transport operators and municipalities have imposed safety measures that were discussed earlier in this research paper.

Taking into consideration the public transport system in Bucharest, the five main aspects that should be considered in order to achieve the desired balance between demand and supply are:

1. The necessary infrastructure

2. The city population

3. User needs

4. An optimum quality assurance

5. An efficient public transport

Finally, to increase the safety and comfort of the public transit, companies can raise the number of buses, trolleybuses, trains and metro trains so people can travel while mantaining social distancing. This can be implemeted on peak hours or on the busy lines. Periodic cleaning and sanitizing of the vehicles are also very important and must be rigorously done.

\section{CONCLUSIONS}

Without doubt, public transport is currently facing challenges in Bucharest and many other metropolitan areas. Even if the problems have not started now, they have intensified since the pandemic crisis began. Public transport has been adapting during the pandemic which accelerated the peace of change. Hopefully, all the changes will have as a result a more dynamic travel behavior than before.

When it comes to research outcome, I've identified that even if the public transport operators were quite quick to introduce safety measures, those are insufficient and way too general. Transport operators and municipalities should aim to organize passenger fluxes in order to accomplish all the needs and respect new regulations while keeping a high efficiency and profitability with acceptable and adequate prices for users.

The absence of quick solutions to the challenges that the public transport system is facing is not a justification to ignore the proportions of the pandemic over the public transport system. Instead, public transport operators should focus on providing mobility for the people without alternatives means and 
remain fact-driven, deliberative, and careful regarding the future of the public transport system. Good intentions don't necessarily translate in good policies.

\section{REFERENCES}

ABC Premium News. (2021a, July 18). Sydney news: NSW offers grants for COVID-hit businesses, public transport services cut in lockdown. Sydney, Australia. Retrieved from https://www.proquest.com/wire-feeds/sydney-news-nsw-offers-grants-covidhit/docview/2552743289/se-2?accountid=136549

ABC Premium News. (2021b, April 14). Sydney News: COVID-19 restrictions on public transport to ease, rental prices hit record high. Sydney, Australia. Retrieved from https://www.proquest.com/wire-feeds/sydney-news-covid-19-restrictions-onpublic/docview/2512761731/se-2?accountid $=136549$

Abu-Rayash, A., \& Dincer, I. (2020, October). Analysis of mobility trends during the COVID-19 coronavirus pandemic: Exploring the impacts on global aviation and travel in selected cities. Energy Research \& Social Science, 68, 1-9. doi:10.1016/j.erss.2020.101693

Agrawal, V., Tripathi, V., \& Agrawal, A. M. (2015). Methodology for evaluating service quality of public transport: Case of Delhi, India. Journal of Supply Chain Management Systems, 4(1), 88-100.

Aloi, A., Alonso, B., Juan, B., Cordera, R., Echániz , E., González , F., . . Sañudo, R. (2020, May 9). Effects of the COVID-19 Lockdown on Urban Mobility: Empirical Evidence from the City of Santander (Spain). Sustainability, 12(9). doi:10.3390/su12093870

Beck, M. J., \& Hensher, D. A. (2020, Decembrie). Insights into the impact of COVID-19 on household travel and activities in Australia - The early days of easing restrictions. Transport Policy, 99, 95-119.

Bucsky, P. (2020, Noiembrie). Modal share changes due to COVID-19: The case of Budapest. Transportation Research Interdisciplinary Perspectives, $1-5$. doi:https://doi.org/10.1016/j.trip.2020.100141

Budd, L., \& Ison, S. (2020, lulie). Responsible Transport: A post-COVID agenda for transport policy and practice. Transportation Research Interdisciplinary Perspectives, 6, 1-2. doi:10.1016/j.trip.2020.100151

Ceylan, H., \& Ozcan, T. (2018). Optimization of headways and departure times in urban bus networks: A case study of Çorlu, Turkey. Advances in Civil Engineering, 1, 1-12.

Ciobanu, R. (2021, August 1). Transportul public în București, mai scump începând de astăzi. Prețul unei călătorii cu metroul sau autobuzul. Retrieved from https://www.libertatea.ro/stiri/tarife-stbmetrorex-1-august-3670564

de Haas, M., Faber, R., \& Hamersma, M. (2020, July). How COVID-19 and the Dutch 'intelligent lockdown' change activities, work and travel behaviour: Evidence from longitudinal data in the Netherlands. Transportation Research Interdisciplinary Perspectives, 6. doi:10.1016/j.trip.2020.100150

De Vos, J. (2020, Mai). The effect of COVID-19 and subsequent social distancing on travel behavior. Transportation Research Interdisciplinary Perspectives, 5, 1-2. 
Flyvbjerg, B., Holm, M., \& Buhl, S. L. (2007). How (In)accurate Are Demand Forecasts in Public Works Projects?: The Case of Transportation. Journal of the American Planning Association, 71(2), 131-146.

Marica, I. (2020, Septembrie 9). Retrieved from Personal car, bicycle or public transport: Study reveals Romanians' transportation preferences during pandemic: https://www.romaniainsider.com/romanians-transportation-preferences-study-covid19

METROREX. (2020, lulie 14). Recomandari de respectare in continuare cu strictete a masurilor de preventie pentru limitarea raspandirii infectiei $c u$ noul coronavirus. Retrieved from METROREX: http://www.metrorex.ro/_read634-1

METROREX. (2021, 06 13). Retrieved from http://www.metrorex.ro/prima_pagina_p1352-1

Munawar, H. S., Khan, S. I., Qadir, Z., Kouzani, A. Z., \& Mahmud, M. P. (2021). Insight into the Impact of COVID-19 on Australian Transportation Sector: An Economic and Community-Based Perspective. Sustainability, 13(3), 1-24. doi:10.3390/su13031276

Nedelea, A., \& Ispas, L. (2020, Mai 11). Anunțul îngrijorător al ministrului transporturilor despre pierderile Metrorex, Tarom și CFR în criza COVID-19: "Trebuie să le menținem în viață" Citeşte întreaga ştire: Anunțul îngrijorător al ministrului transporturilor despre pierderile Metrorex, Tarom. Retrieved from https://www.libertatea.ro/stiri/pierderi-metrorex-tarom-cfrcriza-coronavirus-2993332

Polzin, S. (2021, Martie 25). Mass Transit Systems Face Critical Challenges Now and When COVID-19 Pandemic Is Over. Retrieved from Reason Foundation: https://reason.org/policy-brief/masstransit-systems-face-critical-challenges-now-and-when-covid-19-pandemic-is-over/

Popescu, A. L. (2020, Octombrie 27). Transport în pandemie. Din metrou în autobuz | Unde sunt marile aglomerații. Retrieved from Europa Libera Romania: https://romania.europalibera.org/a/transport-pandemie-din-metrou-autobuz-unde-sunt-marileaglomeratii/30915288.html

STB. (2020). Statistici. Retrieved from Societatea de transport Bucuresti: http://stbsa.ro/statistici

STB. (n.d.). Măsuri pentru evitarea infectării cu virusul Covid-19 (coronavirus). Retrieved August 8, 2021, from Societatea de Transport Bucuresti: http://www.stbsa.ro/coronavirus

Struzik, A. (2020, Decembrie 08). Transportul public după COVID-19 - necesitatea unor soluții inovatoare și sigure pentru actuala criză și posibilele crize viitoare. Retrieved from https://cor.europa.eu/ro/news/Pages/transport-publiczny-po-covidzie.aspx

Tamminen, H. (2020, Martie 26.03.2020). Nysse asigură încă mișcarea de zi cu zi. Retrieved from TAMPERE:

https://www.tampere.fi/tampereenkaupunki/ajankohtaista/tiedotteet/2020/03/26032020_3.html

Tirachini, A., Hensher, D. A., \& Bliemer, M. C. (2014). Accounting for travel time variability in the optimal pricing of cars and buses. Transportation, 947-971. doi:10.1007/s11116-014-9515-8

Wilder-Smith, A., \& Freedman, D. (2020, Martie). Isolation, quarantine, social distancing and community containment: pivotal role for old-style public health measures in the novel coronavirus (2019nCoV) outbreak. Journal of Travel Medicine, 27(2), 1-4. doi:10.1093/jtm/taaa020

Willoughby, C. (2002, lanuarie 1). Infrastructure and Pro-Poor Growth: Implications of Recent Research. Retrieved from GOV.UK: https://www.gov.uk/research-for-development-outputs/infrastructureand-pro-poor-growth-implications-of-recent-research 
Tudor, A.

BUCHAREST PUBLIC TRANSPORT: CHALLENGES DURING THE COVID-19 PANDEMIC

World Health Organization. (2020, Aprilie 27). This statement is no longer maintained. An updated version was published on 29 June 2020. . Retrieved from WHO: https://www.who.int/news/item/27-04-2020-who-timeline---covid-19 